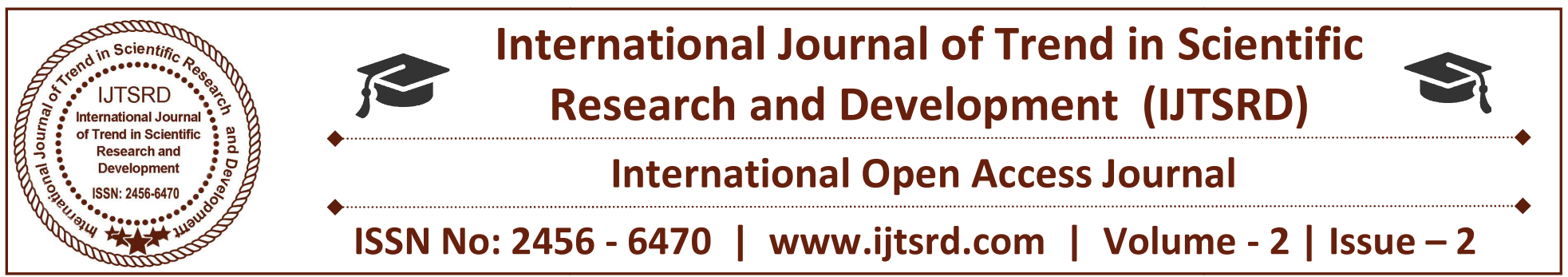

\title{
A Comparative Study between Public and Private Insurance Company in India
}

\author{
Dr. Sakharam Mujalde \\ Sr. Lecturer, School of Economics, DAVV, \\ Indore, Madhya Pradesh, India
}

\author{
Ms. Anshita Kandari \\ Student of Economics, DAVV, \\ Indore, Madhya Pradesh, India
}

\section{ABSTRACT}

Since 1991, Indian economy and industry has moved away from a state controlled to a competitive market with intricate financial services to the global economy. The financial sector, particularly, the Insurance has opened up to all competition. A revamp in tightly regulated and monopolized insurance sector was brought about by the passage of the Insurance Regulatory and Development Authority Act (IRDA) in 1999. The present paper and lyses the performance of public and private life insurance companies in India. As per the total premium income, in FY 2014 15 , LIC with $73 \%$ of business share still holds a significant market share. 24 private insurance companies have established footholds in the market leading to intense competition. Private Insurance companies have a higher growth rate as compared to public sector. Today, Insurance penetration is better. The Insurance companies are competing in terms of policies sold, collection of premium income and others.

\section{INTRODUCTION}

The need for insurance is as old as commerce and trading in the civilized world. Risk is inherent to life, commerce, trading etc. The insurance will provide safety to it. Insurance sector has been playing a leading role in the financial system of India. It has also been facilitating an objective to build an efficient, effective and a stable economic environment in India. It also caters to the needs of the both real economy and socio-economic objective of the country. It is making inroads into the interiors of the economy and is being considered as one of the fast developing areas in the Indian financial sector. It has been mobilizing long-term saving through life insurance to support economic growth and also facilitating economic Development. Life Insurance business in India was nationalized by incorporating Life Insurance Corporation of India" (LIC) in 1956. After the Indian economic reform 1991 there was a significant improvement in the Indian insurance sector which is characterized by Liberalization, Privatization and Globalization (LPG). In year1993 the Malhotra Committee emphasized on privatization of life insurance business.

The Indian insurance industry was opened for private insurers in the year 1999, with the establishment of Insurance Regulatory and Development Authority Act (IRDA Act). Before liberalization there was monopoly of Life Insurance Corporation of India (LIC). The entry of private companies in life insurance business breaks the monopoly of LIC. The Insurance Regulatory and Development was established to regulate and to protect the policyholder's interest of the insurance industry. Indian life insurance is the fastest growing sector, with many domestic and foreign players. The government of India allowed private insurers in year 2000 with $26 \%$ foreign direct investment. In the post liberalization era, the life insurance sector of India witnessed a significant growth as there is healthy competition from many domestic as well as foreign private insurers. There is tremendous growth potential for life insurance sector in India as we have huge population and still the 
Indian life insurance market is untapped. Further, it indicates the growth prospects and a huge potential for life insurance business in the country Life Insurance is a professional service which is characterized by high involvement of the consumers, due to the importance of tailoring specific need, the variability of the products available, the complexity involved in the policies and processes and ultimately the need to involve the consumer in every aspect of the transaction. Life insurance more fondly known as Life Assurance has, in recent times ceased to be only a „Protection"e or 'Legacy' for the family and has turned into an important investment outlet.

India's economic development made it a most lucrative Insurance market in the world. Before the year 1999, there was monopoly state run Life Insurance Corporation of India (LIC) transacting life business. Today, there are 24 private life insurance companies operating insurance business in India. The competition from these companies was threatening to the existence of LIC. Since the liberalization of the industry the insurance industry has never looked back and today stand as the one of the most competitive and exploring industry in India. In this paper, an attempt is made to analyze the performance of public and private life insurance companies India

\section{REVIEW OF LITERATURE}

A thriving insurance sector is of vital importance to every modern economy. It encourages the savings habit, it also provides a safety net to rural and urban enterprises and productive individuals, and most importantly it generates long-term invest-able funds for infrastructure building. The nature of the insurance business is such that the cash inflow of insurance companies is constant while the payout is deferred and contingency related (Kumar, 2010). During middle of 20th Century life insurance companies started to operate the evil play natural to all business had its sway. Numbers of competitors were entered and abolished while profiteering. On $1^{\text {st }}$ September 1956, Life Insurance Corporation of India came into existence after nationalization of all 245 insurance providing companies. Malhotra Committee was constituted by the government in 1993 to examine the various aspects of the insurance industry. The key element of the reform process was Participation of overseas insurance companies with $26 \%$ capital. Creating a more efficient and competitive financial system suitable for the requirements of the economy was the main idea behind this reform (Kannan, 2010). In 1999, Insurance Regulatory and Development Authority (IRDA) has been established to regulate the insurance business in the country (Chaudhary and Kiran, 2011).

Sinha (2005) in his paper highlights the phenomenal growth experienced recently in connection with improvements in economic fundamentals. With comparison in growth, penetration, density and other insurance variables it can be said that still India is an underdeveloped insurance market with huge catch -up potential. It is found that there is potential for expansion of insurance into rural areas, growth has remained slow. Chandrasekhar (2009) in his article "Learning Nothing, Forgetting Everything" observes that the Government has been pushing ahead with privatization despite there being no evidence of the nationalized insurance industry failing to meet its obligation to insurers or to the Government. The LIC has not only put at the Government's disposal large volumes of capital for investment but also addressed the problems of insurance for the poor. Krishnaswami (2009) in his book "Principles and Practice of Life Insurance" explains clearly the history of insurance, advantages of insurance and the role of insurance in the economy and also in the society. The life insurance products, the concepts of premium, investment management and solvency margin are also discussed at length in the book.

Kannan (2010) viewed that India, being rich in population and most of the area is untapped, has tremendous scope for growth in insurance sector. Today insurance business is growing at the rate of 15$20 \%$ annually. Together with banking services, it adds about $7 \%$ to the country's GDP. In spite of all this growth the statistics of the penetration of the insurance in the country is very poor. Nearly $80 \%$ of Indian populations are without Life insurance cover and the Health insurance. This is an indicator that growth potential for the insurance sector is immense in India. Imam (2011) analyzed Customer behaviors in Life Insurance Industry. Researcher opined that the sale of life insurance policies in India is less than many western and Asian countries. As second largest populated country in world, the Indian insurance market is looking very prospective to many multinational and Indian insurance companies for expanding their business and market share. With their world market experience and network, these 
companies have offered many good schemes to lure all type of Indian consumers, but unfortunately failed to get the major share of market. Still the LIC is the biggest player in the life insurance market with approx. 65\% market share. Selvakumar \& Piyan (2012) analyzed the performance of public and private life insurance companies in India. Researcher opined that today's market is customer centric, and customer is supposed to be king of market. To satisfy customers innovations are taking place with distinct features to attract the customers.

Tiwari \& Yadav (2012) conducted a Analytical study on Indian Life Insurance Industry in Post liberalization. Researchers concluded that Indian market is untapped market and found good opportunity. After 1991, the Indian life insurance industry has geared up in all respects and able to avail healthy competition from in -house and abroad players. Motwani and Anchliaa (2013) conducted and study in Udaipur city to study comparative behavior between public and private insurance companies. That was based on descriptive research design, in which a Close ended questionnaire was used to collect the primary data from customers of various Insurance companies. Conclusions of study reveal the impact of customers ${ }^{\text {ce }}$ demography on their choice Between Public \& Private Insurance companies. Sharma and Chouhan (2013) in the research paper "A Comparative Study of Public \& Private Life Insurance", made an attempt to analyze the performance of public and private life insurance companies in India. Researchers concluded that with the entry of private players, the competition is becoming intense. In order to satisfy the customers, every company is trying to implement new creations and innovative product characteristics to attract customers.

\section{Research Objectives:}

The objective of the present study is to compare the performance of public and private life insurance companies for period of 2005-06 to 2014-15. For the purpose of the main objective, the following objectives are formed:-

$>$ The $\mathbf{1}^{\text {st }}$ objective of the present study is to compare the growth rate of fresh business premium between public and private life insurance companies.

$>$ The $\mathbf{2}^{\text {nd }}$ objective of the present study is to compare the growth of number of new policies issued among public and private life insurance companies.

$>$ The $3^{\text {rd }}$ objective of the present study is to compare the growth rate of total life insurance premium among public and private life insurance companies.

\section{Research Hypothesis:}

For the purpose of this study, the following null hypotheses are formed:-

H01: There is no significant difference in the growth rate of fresh business premium between public and private life insurance companies.

H02: There is no significant difference in the growth of number of new policies issued among public and private life insurance companies.

H03: There is no significant difference in the growth rate of total life insurance premium among public and private life insurance companies.

\section{Research Methodology:}

The research paper is based upon descriptive as well as exploratory research. Secondary sources of data collection have been adopted for the study. The relevant and required data are collected from the annual reports of IRDA from 2005-06 to 2014-15. The performance of insurance companies is examined further by looking at the trend.

\section{Analytical Tools:}

In order to analyze the collected data the following mathematical tools are employed:

a) Annual Growth Rate is worked out by using the following formula:

$\mathbf{A G R}=(\mathrm{X} 2-\mathrm{X}) / \mathrm{X} 1 \times \mathbf{X} \mathbf{1 0 0}$

Where $\mathrm{X} 1$ = first value of variable $\mathrm{X}$

$\mathrm{X} 2$ = second value of variable $\mathrm{X}$

b) To confirm significance in difference of growth, Mann -Whitney U-test is used:
$\mathbf{U}=\mathbf{N} 1 \mathbf{X} \mathbf{N} 2+\mathbf{N x}$
$\mathrm{Nx}+1 / 2-\mathrm{Tx}$

Where, N1 and N2 are the Number of the data in each group.

$\mathrm{Nx}$ is the Number of the data in the group that gave the larger rank total. Tx is the larger rank total

\section{Analysis:}

In December 1999, a bill was passed in the parliament with the passage of Insurance Regulatory and 
International Journal of Trend in Scientific Research and Development (IJTSRD) ISSN: 2456-6470

Development Authority for its reform process. However with the setting up of IRDA, the government has once again deregulated the sector by opening it for the private players. Life Insurance Corporation of India (L.I.C.I) dominated the Indian Life Insurance market. But the situation drastically changed since the beginning of the year 2000. With the development of the IRDA Act in 1999, private players started entering into the life insurance market. At the end of March 2015, there are 53 insurance companies operating in India; of which 24 are in the life insurance business including one public sector company (L.I.C. of India) and 28 are in non-life insurance business. On the basis of total premium income, the market share of LIC decreased from 75.39 per cent in 2013-14 to 73.05 per cent in 201415. The market share of private insurers has increased from 24.61 per cent in 2013-14 to 26.95 per cent in 2014-15. So, we can say that the state-owned Life
Insurance Corporation (LIC) still holds a significant majority of market share, though, other companies have established footholds.

\section{Analysis of Data:}

a. Growth in Fresh Life Insurance Premium Table 1 shows the trends of fresh life insurance premium of LIC of India and private insurance companies operating in India. This table reveals that growth in fresh life insurance premium for LIC is having a mixed trend and its growth rate varies from $-13.55 \%$ (FY 2014-15) and 97.17\% (FY 2007-08). In private sector also there is a mixed trend in the fresh business premium during the years from 2005-06 to 2014-15. The rate of annual growth was highest in FY 2006-07 $(89.16 \%)$ and it was lowest in FY 2011-12 (-18.49).

Table 1: Details of Fresh Life Insurance Premium of LIC and Private Insurance Companies (Amount in Rs. Crore)

\begin{tabular}{|c|c|c|c|c|}
\hline \multirow[t]{2}{*}{ Year } & \multicolumn{2}{|l|}{ LIC } & \multicolumn{2}{|c|}{ Private Insurance Companies } \\
\hline & Amount & AGR (\%) & Amount & AGR (\%) \\
\hline $2005-06$ & 28515.87 & 38.07 in Sci & 10269.67 & 84.55 \\
\hline $2006-07$ & 56223.56 & 97.17 & 19425.65 & 89.16 \\
\hline $2007-08$ & 59996.57 & 6.71 ealloria & 3371595 & 73.56 \\
\hline 2008-09 & 53179.08 & $-11.36 \mathrm{lnm}$ & 34152.00 & 1.29 \\
\hline $2009-10$ & 71521.90 & 34.49 & 38372.01 & 12.36 \\
\hline $2010-11$ & 87012.35 & 21.66 & 39385.84 & 2.64 \\
\hline 2011-12 & 81862.25 & $-5.92<400=04$ & 32103.78 & -18.49 \\
\hline $2012-13$ & 76611.50 & -6.41 & 30749.58 & -4.22 \\
\hline 2013-14 & 90808.79 & 18.53 & 29516.43 & -4.01 \\
\hline $2014-15$ & 78507.71 & -13.55 & 34820.23 & 17.97 \\
\hline
\end{tabular}

Table 2: Mann-Whitney U-test for Fresh Life Insurance Premium of Public And Private Insurance Companies

\begin{tabular}{|l|l|l|l|l|}
\hline Financial Year & LIC & \multicolumn{2}{l|}{ Private Companies } \\
\hline & AGR & Rank & AGR & Rank \\
\hline $2005-06$ & 38.07 & 16 & 84.55 & 18 \\
\hline $2006-07$ & 97.17 & 20 & 89.16 & 19 \\
\hline $2007-08$ & 6.71 & 10 & 73.56 & 17 \\
\hline $2008-09$ & -11.36 & 3 & 1.29 & 8 \\
\hline $2009-10$ & 34.49 & 15 & 12.36 & 11 \\
\hline $2010-11$ & 21.66 & 14 & 2.64 & 9 \\
\hline $2011-12$ & -5.92 & 5 & -18.49 & 1 \\
\hline $2012-13$ & -6.41 & 4 & -4.22 & 6 \\
\hline $2013-14$ & 18.53 & 13 & -4.01 & 7 \\
\hline $2014-15$ & -13.55 & 2 & 17.97 & 12 \\
\hline
\end{tabular}


International Journal of Trend in Scientific Research and Development (IJTSRD) ISSN: 2456-6470

\begin{tabular}{|l|l|l|}
\hline Sum of Rank order & 102 & 108 \\
\hline No. of Data & 10 & 10 \\
\hline U-value & & 47 \\
\hline
\end{tabular}

For $\mathrm{N}_{1}=10$ and $\mathrm{N}_{2}=10$, the critical value of $\mathrm{U}$ is 23 for a two-tailed test at the 0.05 significance level and 16 for a two-tailed test at the 0.01 significance level.

Our Obtain value of $U=47$ which is more than critical value of $U$ (23) at significance level 0.05 , So, it can be said that difference in growth rate of fresh insurance premium of LIC and Private Insurance companies is not significant at $\mathrm{p}=0.05$.

b) Growth in New Life Insurance Policies issued

Table 3 : Details of New Life Insurance Policies issued by Public And Private Insurance Companies

(FY 2005-06 to FY 2014-15) (Numbers in Lakh)

\begin{tabular}{|l|l|l|l|l|}
\hline Financial Year & \multicolumn{2}{|l|}{ LIC } & \multicolumn{2}{l|}{ Private Companies } \\
\hline & No. of Policy & AGR (\%) & No. of Policy & AGR (\%) \\
\hline $2005-06$ & 315.91 & 31.75 & 38.71 & 73.35 \\
\hline $2006-07$ & 382.29 & 21.01 & 79.22 & 104.65 \\
\hline $2007-08$ & 376.13 & -1.61 & 132.62 & 67.41 \\
\hline $2008-09$ & 359.63 & -4.52 & 150.11 & 13.19 \\
\hline $2009-10$ & 388.63 & 8.21 & 143.62 & -4.32 \\
\hline $2010-11$ & 370.38 & -4.70 & 111.14 & -22.62 \\
\hline $2011-12$ & 357.51 & -3.47 & 84.42 & -24.04 \\
\hline $2012-13$ & 367.82 & 2.88 & 74.05 & -12.28 \\
\hline $2013-14$ & 345.12 & -6.17 & 63.30 & -14.11 \\
\hline $2014-15$ & 201.71 & -41.55 & 57.37 & -9.79 \\
\hline
\end{tabular}

Table 3 presents the yearly data related to new life insurance policies issued for the period of FY 2005-06 to 2014-15. It indicate that growth rate of new life insurance policies issued by LIC is having mixed trend as the annual growth in the numbers of new policies issued by LIC is was highest in FY 2005-06 (31.57\%) and lowest in FY 2014-15 (41.55\%). Private insurance companies have also registered mixed growth and its annual growth rate varies between 104.65\% (FY 2006-07) and -24.04\% (FY 2011-12)

Table 4: Mann-Whitney U-test for New Life Insurance Policies issued by LIC and Private Insurance Companies

\begin{tabular}{|l|l|l|l|l|}
\hline Financial Year & LIC & \multicolumn{2}{l|}{ Private Companies } \\
\hline & AGR & Rank & AGR & Rank \\
\hline $2005-06$ & 31.75 & 17 & 73.35 & 19 \\
\hline $2006-07$ & 21.01 & 16 & 104.65 & 20 \\
\hline $2007-08$ & -1.61 & 12 & 67.41 & 18 \\
\hline $2008-09$ & -4.52 & 9 & 13.19 & 15 \\
\hline $2009-10$ & 8.21 & 14 & -4.32 & 10 \\
\hline $2010-11$ & -4.70 & 8 & -22.62 & 3 \\
\hline $2011-12$ & -3.47 & 11 & -24.04 & 2 \\
\hline $2012-13$ & 2.88 & 13 & -12.28 & 5 \\
\hline $2013-14$ & -6.17 & 7 & -14.11 & 4 \\
\hline $2014-15$ & -41.55 & 1 & -9.79 & 6 \\
\hline
\end{tabular}

\begin{tabular}{|l|l|l|}
\hline Sum of Rank order & 108 & 102 \\
\hline No. of Data & 10 & 10 \\
\hline U-value & & 47 \\
\hline
\end{tabular}


Our Obtain value of $U=47$ which is more than critical value of $U(23)$ at significance level 0.05 , So, it can be said that difference in growth rate of New insurance policies issued by LIC and Private Insurance companies yearly is not significant at $\mathrm{p}=0.05$.

c) Growth in Total Life Insurance Premium

Table 5 indicates that the total life insurance premium of LIC of India was Rs. 90792.22 Crore in 2005-06 and it has increased to Rs. 239667.65 Crore in 2014- insurance premium of LIC of India, except in FY 2011-12, when it has registered a negative annual growth $(-0.29 \%)$. The total life insurance premium of private insurance companies was 15083.54 Crore in 2005-06 and it has continuously increased to 79369.94 Crore in 2009-10. After 2009-10, it has shown mixed trend in annual growth rate and at the end of FY 2014-15, the total life insurance premium of private insurance companies was Rs. $88433.49 \mathrm{Cr}$.

Table 5: Details of Total Life Insurance Premium of Public and Private Insurance Companies (Amount in Carore

\begin{tabular}{|l|l|l|l|l|}
\hline Financial Year & LIC & \multicolumn{2}{l|}{ Private Companies } \\
\hline & Amount & (AGR \%) & Amount & (AGR \%) \\
\hline $2005-06$ & 90792.22 & 20.85 & 15083.54 & 95.19 \\
\hline $2006-07$ & 127822.84 & 40.79 & 28253.00 & 87.31 \\
\hline $2007-08$ & 149789.99 & 17.19 & 51561.42 & 82.50 \\
\hline $2008-09$ & 157288.04 & 5.01 & 64497.43 & 25.09 \\
\hline $2009-10$ & 186077.31 & 18.30 & 79369.94 & 23.06 \\
\hline $2010-11$ & 203473.40 & 9.35 & 39385.84 & -50.38 \\
\hline $2011-12$ & 202889.28 & -0.29 & 84182.83 & 113.74 \\
\hline $2012-13$ & 208803.58 & 2.92 & 78398.91 & -6.87 \\
\hline $2013-14$ & 236942.30 & 13.48 & 77340.90 & -1.33 \\
\hline $2014-15$ & 239667.65 & 1.15 & 88433.49 & 14.32 \\
\hline
\end{tabular}

To ascertain the significance of difference in growth rate of total life insurance premium for LIC and private insurance companies, Mann-Whitney U-test is carried out:

Table 6: Mann-Whitney U-test for Total Life Insurance Premium of LIC and Private Insurance Companies

\begin{tabular}{|l|l|l|l|l|}
\hline Financial Year & LIC & Rank & PGR & Rank \\
\hline & AGR & 13 & 95.19 & 19 \\
\hline $2005-06$ & 20.85 & 16 & 87.31 & 18 \\
\hline $2006-07$ & 40.79 & 11 & 82.50 & 17 \\
\hline $2007-08$ & 17.19 & 7 & 25.09 & 15 \\
\hline $2008-09$ & 5.01 & 12 & 23.06 & 14 \\
\hline $2009-10$ & 18.30 & 8 & -50.38 & 1 \\
\hline $2010-11$ & 9.35 & 4 & 113.74 & 20 \\
\hline $2011-12$ & -0.29 & 6 & -6.87 & 2 \\
\hline $2012-13$ & 2.92 & 9 & -1.33 & 3 \\
\hline $2013-14$ & 13.48 & 5 & 14.32 & 10 \\
\hline $2014-15$ & 1.15 & & \\
\hline
\end{tabular}

\begin{tabular}{|l|l|l|}
\hline Sum of Rank order & 91 & 119 \\
\hline No. of Data & 10 & 10 \\
\hline U-value & & 36 \\
\hline
\end{tabular}


Our Obtain value of $U=36$ which is more than critical value of $U(23)$ at significance level 0.05 , i.e. it can be said that difference in growth rate of Total insurance premium of LIC and Private Insurance companies is non-significant at $\mathrm{p}=0.05$.

\section{RESULT AND DISCUSSION}

$\mathbf{H}_{0}$ 1: - For $\mathrm{N}_{1}=10$ and $\mathrm{N}_{2}=10$, Obtain value of $\mathrm{U}$ for growth rate of fresh life insurance premium (47) is more than critical value of $U$ (23) at significance level 0.05 ,So,it can be said that difference in growth rate of fresh insurance premium of LIC and Private Insurance companies is not significant at $p=0.05$.It proves the null hypothesis $\mathrm{H}_{0} 1$ "There is no significance difference in the growth rate of fresh life insurance premium between public and private life insurance companies.

$\mathbf{H}_{0}$ 2- For $\mathrm{N}_{1}=10$ and $\mathrm{N}_{2}=10$, Obtain value of $\mathrm{U}(47)$ is more than critical value of $U(23)$ at significance level 0.05 ,So,it can be said that difference in growth rate of new insurance policies issued by LIC and Private Insurance companies yearly is not significant at $\mathrm{p}=0.05$.It proves the null hypothesis $\mathrm{H}_{0} 2$ "There is no significant difference in the growth of number of new policies issued among public and private life insurance.
$\mathbf{H}_{0} 3$ - For $\mathrm{N} 1=10$ and $\mathrm{N} 2=10$, Obtain value of $U$ (39) is more than critical value of $U$ (23) at significance level 0.05 ,i.e. it can be said that difference in growth rate of Total insurance premium of LIC and Private Insurance companies is not significant at $p=0.05$. It proves the null hypothesis H03 "There is no significant difference in the growth rate of total life insurance premium among public and private life insurance companies."

\section{CONCLUSION}

The life insurance plays a significant role in supplying long -term capital to national economy and accelerating the process of self generation of the gross production of national saving. The Indian life insurance system is having significant base on mixed economic system where in the public sector occupied a monopolistic position in life insurance business. Private players play a major role in life insurance business more efficient and customer friendly. They have also jolted and facing stiff competition from the LIC. It is therefore, by the expansion of population, share of private sector life insurance companies in fresh life insurance premium has increased from merely $26.48 \%$ in FY 2005-06 to $30.73 \%$ in FY 201415 and in issuing of new insurance policies from $10.92 \%$ in FY $2005-06$ to $22.14 \%$ in FY $2014-15$ is remarkable (Table 7).

Table No. 7: Share of LIC and Private Life Insurance Companies

\begin{tabular}{|l|l|l|l|l|l|l|}
\hline $\begin{array}{l}\text { Financial } \\
\text { Year }\end{array}$ & \multicolumn{2}{l}{$\begin{array}{l}\text { Share in Total Fresh } \\
\text { Life Insurance Premium }\end{array}$} & \multicolumn{2}{l}{$\begin{array}{l}\text { Share in Insurance } \\
\text { Policies Issued }\end{array}$} & $\begin{array}{l}\text { Share in Total life } \\
\text { Insurance Premium }\end{array}$ \\
\hline & LIC & PICs & LIC & PICs & LIC & PICs \\
\hline $2005-06$ & 73.52 & 26.48 & 89.08 & 10.92 & 85.75 & 14.25 \\
\hline $2006-07$ & 74.32 & 25.68 & 82.83 & 17.17 & 81.90 & 18.10 \\
\hline $2007-08$ & 64.02 & 35.98 & 73.93 & 26.07 & 74.39 & 25.61 \\
\hline $2008-09$ & 60.89 & 39.11 & 70.52 & 29.48 & 70.92 & 29.08 \\
\hline $2009-10$ & 65.08 & 34.92 & 73.02 & 26.98 & 70.10 & 29.90 \\
\hline $2010-11$ & 68.84 & 31.16 & 76.92 & 23.08 & 83.78 & 16.22 \\
\hline $2011-12$ & 71.83 & 28.17 & 80.90 & 19.10 & 70.68 & 29.32 \\
\hline $2012-13$ & 71.36 & 28.64 & 83.24 & 16.76 & 72.70 & 27.30 \\
\hline $2013-14$ & 75.47 & 24.53 & 84.44 & 15.56 & 75.39 & 24.61 \\
\hline $2014-15$ & 69.27 & 30.73 & 77.86 & 22.14 & 73.05 & 26.95 \\
\hline
\end{tabular}

The share of private Sector life insurance companies in total life insurance premium is also increased from $14.25 \%$ in FY 2005-06 to 26.95\% in FY 2014-15 (Table 7). It is clear evidence Private Insurance Companies have made their presence felt and over the years have achieved remarkable progress. There is a big opportunity to these companies in the Indian Life Insurance Sector. The companies have to bring out innovative products to suit the different requirements of the public. A healthy competition in the sector 
would be beneficial to both the players and also the public

\section{REFERENCES}

1. Annual Report of Insurance Regulatory and Development Authority of India (IRDA), Hyderabad, (200 5-06 to 2014-15) .

2. Chandrasekhar, C.P. (2009), "Learning Nothing, Forgetting Everything”, Frontline, Jan. 16.

3. Chaudhary, Sonika and Priti Kiran (2011), "Life Insurance Industry in Indi Current Scenario", IJMBS, Vol.-1, Issue-3, Sep., pp. 146-150.

4. Imam, Ashraf (2011), "Analyzing Customer behaviors in Life Insurance Industry", Asian Journal of Research in Social Sciences and Humanities, Vol.- 1, Issue 1.Kannan, N. (2010), "A study on the Growth of Indian Insurance Sector", International Journal of Management, Vol. - 1, Issue-1, May, pp. 17-32.

5. Krishna swami G. (2009), "Principles and Practice of Life Insurance”, Excel Books, New Delhi.

6. Motwani, Dharmesh and Kiran Anchliaa (2013), "Comparative Study of Customer Behavior between Public and private Insurance Companies (With Special Reference to Udaipur City)", RIJM, Vol. -2, Issue-3, March, pp. 1-11.

7. Tiwari, Anshuja \& Babita Yadav (2012), "Analytical study on Indian Life Insurance Industry in Post liberalization", International Journal of Social science Tomorrow, Vol.-1, No.2, April, PP-1-10.

8. Selvakumar, M. \& J. Vimal Priyan (2012)," A Comparative study of Public \& Private Life insurance companies in India", Indian Journal of Commerce, Vol.-65, Issue-2, March 2012, pp. 8187.

9. Sharma, Ravikant (2012), "A comparative study on Deliveries of Service on Life Insurance Sector: India vs China",

10. The International Journal's Research Journal of Social Sciences \& Management, Vol. -1, Issue-11, March, pp. 7-9.
11. Sharma, V. and S.S. Chowhan (2013), A Comparative Study of Public \& Private Life Insurance, Indian Journal of Applied Research, Vol.-3, Issue-1, Jan., pp. 93-94.

12. Sinha, Tapan (2005), "The Indian Insurance Industry: Challenges and prospects", Centre for Risk \& Insurance Studies, Discussion Paper studies, Vol.-X, pp 25-26.

13. Shrivastava, Arnika \& Sarika Tripathi (2012), "Indian Life Insurance Industry-The changing Trends", Researchers World- Journal of Arts, Science \& Commerce, Vol.-III, Issue-2(3), April, $\mathrm{pp}$ 